\title{
Study of the Causes of Mortality in Acute Aluminium Phosphide Poisoning
}

\author{
Hany Mohamed Tawfik ${ }^{1}$
}

\begin{abstract}
KEYWORDS

Aluminium phosphide, Suicide,

Mortality,

Shock,

Acidosis,

Arrhythmia

Aluminum phosphide (ALP) poisoning has aroused interest in the past three decades. The percentage of poisoning is low, but the mortality is high and no effective antidote available. The objective of this study was to find out predictors of mortality for patients with acute aluminium phosphide poisoning. All patients with acute aluminium phosphide poisoning admitted to Poisoning Control Center, Ain Shams University Hospital between the years 2015 to 2017 were prospectively studied and compared between survival and non survivor patients. Data collected include demographic data, clinical manifestations, laboratory parameters, ECG and treatment offered to the patients. A total 31 patients were enrolled comprising 20 males and 11 females, $84 \%$ were suicide and mortality rate was $35 \%$. Shock and cardiac arrhythmia were observed in $52 \%$ and39\% respectively, while $26 \%$ presented with coma. Abnormal blood sugar and metabolic acidosis were found in $19 \%$ and $45 \%$ respectively. Fifty two percent of the patients needed inotropic therapy and $32 \%$ received N-acetylcysteine (NAC). Risk factors increasing mortality were found as shock, tachycardia, coma, metabolic acidosis, hyperglycemia, cardiac arrhythmia and the need for inotropic drug therapy. The study concluded that aluminum phosphide is a low-cost highly-toxic rodenticide. The circulatory collapse, metabolic acidosis and cardiac arrhythmia are the major causes of death. The role of NAC must be reassessed in larger scale. So, intensive observation in ICU and aggressive symptomatic management should be urgently taken into consideration.
\end{abstract}

\section{Introduction}

Aluminium phosphide (ALP) is used for crop protection in storage and transport, it improved the quantity and quality of agricultural products, yet the risk of mortality associated with phosphide poisoning in humans is high (Hassanian, 2014). After ingestion, phosphine will be released due to contact between aluminium phosphide and water/acid in the gastrointestinal (GI) tract. Phosphine gas can rapidly be absorbed by the lungs, GI tract

\footnotetext{
(1) Poisoning Control Center, Ain Shams University Hospitals.
}

and can easily be distributed in all tissues (Gurjar et al., 2011). At the cellular level, phosphine gas inhibits cytochrome $\mathrm{C}$ oxidase, oxidative phosphorylation, catalase and deplete glutathione, which may result in cellular wall damage (Anand et al., 2013).

Hypotension and shock ensue within 3-6 hours of ingestion due to arrhythmia, conduction disturbance, myocardial damage and excessive vomiting with fluid loss. Also shock can be attributed to wide spread small vessel injury leads to peripheral vasodilatation and direct toxic effects of phosphine on adrenal cortex accompanied by decreased cortisol levels. The major complications of ALP 
poisoning include cardiac arrhythmias, circulatory failure and severe metabolic acidosis. In survivors, the cardiotoxicity and hypoxia disappear within 5-7 days due to excretion of phosphine (Nosrati et al., 2013). The objective of this study was to find out predictors of mortality for patients with acute aluminium phosphide poisoning.

\section{Subjects and Methods}

This study is a prospective study included cases with acute ALP poisoned patients who were admitted to Poisoning Control Center; Ain Shams University Hospital (PCCA) from January 2015 to December 2017. The total number of cases is 31 cases; the diagnosis of acute ALP was based on history of consumption of the poison (obtained from the patient or the closest relative). Patients with an unclear diagnosis of poisoning or consumption of more than one substance were excluded from the study. The cases were classified according to the outcome into two groups: survivors and non survivors group. The data gathered included : age, gender, mode of poisoning (suicidal/ accidental), the delay in presentation to hospital, period of stay, conscious level, heart rate, blood pressure, presence or absence of vomiting, laboratory parameters include ( blood sugar, acid base status, liver enzymes and renal function tests), ECG, the need of inotropic drugs and $\mathrm{N}$ acetylcysteine (NAC) therapy. All patients were admitted to ICU after initial resuscitation. A baseline electrocardiogram was recorded and blood samples for biochemical investigations were taken at time of presentation to the hospital.
Ethical consideration:

Permission for the study was obtained from the Director of the Poison Control Center, Ain Shams University Hospitals and the regional ethics committee. All data were stored anonymously. Relatives of recruited patients provided written informed consent for participation.

\section{Statistical Analysis}

Data were analyzed using IBM SPSS 22 statistical soft ware. The categorical data were reported in number and percentage and continuous data were reported as mean and standard deviation. The difference of frequency between two groups was analyzed by chisquare test for categorical data and by $\mathrm{t}$ - test for continuous data. Odds ratio (logistic regression analysis) were used to detect the predictor of outcome. $\mathrm{P}$ value less than 0.05 was considered statistically significant.

\section{Results}

As regard the gender, $65 \%$ of the patients were male, $84 \%$ were suicidal and all the non survivor patients were due to suicidal cause. The period of the stay was less than one day in $71 \%$ of the patients and more than one day in $29 \%$ of the patients. The mean age was $23 \pm 14$ years in survivor group versus $25 \pm 11$ years in the non-survivor and the delay time was $5 \pm 2 \mathrm{~h}$ in the survivor group versus $4 \pm 2 \mathrm{~h}$ in the nonsurvivor. The statistical analysis revealed no significant difference between non survivor and survivor groups as regards, sex, mode of poisoning, age and delay time of presentation 
to hospital and there is significant difference between both groups as regards period of stay at hospital and patients who died usually die in the first day. So, if patients pass the first day, there is a good chance to survive (Table 1).

Table (1): Statistical analysis of the gender, mode of poisoning, period of stay, age and delay time of presentation to hospital for both studied groups.

\begin{tabular}{|c|c|c|c|c|c|}
\hline Parameters & $\begin{array}{c}\text { Non survivor } \\
\text { group } \\
\mathbf{n}=\mathbf{1 1}\end{array}$ & $\begin{array}{c}\text { Survivor } \\
\text { group } \\
\mathbf{n}=\mathbf{2 0}\end{array}$ & $\begin{array}{l}\text { Total } \\
\mathrm{n}=\mathbf{3 1}\end{array}$ & Statistic test & $\mathbf{p}$ \\
\hline \multicolumn{6}{|l|}{ Gender } \\
\hline Males & 7 & 13 & $20(65 \%)$ & \multirow{2}{*}{$\mathrm{X}_{\mathrm{ChS}}^{2}=0.006$} & \multirow{2}{*}{0.9} \\
\hline Females & 4 & 7 & $11(35 \%)$ & & \\
\hline \multicolumn{6}{|l|}{ Mode of poisoning } \\
\hline Suicidal & 11 & 15 & $26(84 \%)$ & \multirow{2}{*}{$\mathrm{X}_{\mathrm{ChS}}^{2}=3.3$} & \multirow{2}{*}{0.07} \\
\hline Accidental & 0 & 5 & $5(16 \%)$ & & \\
\hline \multicolumn{6}{|c|}{ Period of stay at hospital } \\
\hline$<1$ day & 11 & 11 & $22(71 \%)$ & \multirow{2}{*}{$\mathrm{X}_{\mathrm{ChS}}^{2}=6.9$} & \multirow{2}{*}{$0.008^{*}$} \\
\hline$>1$ day & 0 & 9 & $9(29 \%)$ & & \\
\hline \multicolumn{6}{|l|}{ Age } \\
\hline $\begin{array}{l}\text { Age (years) } \\
\text { Mean } \pm \text { SD }\end{array}$ & $25 \pm 11$ & $23 \pm 14$ & $24 \pm 13$ & $\mathrm{t}=0.4$ & 0.7 \\
\hline \multicolumn{6}{|c|}{ Delay time of presentation to hospital } \\
\hline $\begin{array}{l}\text { Delay Time } \\
\text { (hours) } \\
\text { Mean } \pm \text { SD }\end{array}$ & $4 \pm 2$ & $5 \pm 2$ & $4.5 \pm 2$ & $\mathrm{t}=1.1$ & 0.3 \\
\hline
\end{tabular}

$\mathrm{n}$ : number, SD: standard deviation, * significant

As regard the clinical presentation, 39\% of the patients presented with abnormal heart rate (nine patients in the non survivor group: four patients had no palpable pulse, three patients had tachycardia and two patients had bradycardia, versus three patients in the survivor group: one patient with no palpable pulse, one patient had tachycardia and one patient had bradycardia. Fifty two percent were shocked (all the patients in the non survivor group presented with shock versus five patients in the survivor group), $26 \%$ had coma and $48 \%$ had vomiting. The statistical analysis revealed significant difference between both groups as regard heart rate, blood pressure and level of consciousness (Table 2). 
Table (2): Statistical analysis of the clinical parameters for both studied groups.

\begin{tabular}{|c|c|c|c|c|c|}
\hline Parameters & $\begin{array}{c}\text { Non } \\
\text { survivor } \\
\text { group } \\
\mathbf{n}=\mathbf{1 1}\end{array}$ & $\begin{array}{c}\text { Survivor } \\
\text { group } \\
\mathbf{n}=\mathbf{2 0}\end{array}$ & $\begin{array}{l}\text { Total } \\
\mathbf{n}=\mathbf{3 1}\end{array}$ & $\begin{array}{l}\text { Chi-square } \\
\text { test }\left(\chi^{2}\right)\end{array}$ & $\mathbf{p}$ \\
\hline \multicolumn{6}{|l|}{ Heart rate (HR) } \\
\hline $\begin{array}{l}\text { Abnormal } \\
\text { Not palpable } \\
\text { Tachycardia } \\
\text { Bradycardia } \\
\end{array}$ & $\begin{array}{l}9 \\
\text { (4) } \\
(3) \\
\text { (2) } \\
\end{array}$ & $\begin{array}{c}3 \\
(1) \\
(1) \\
(1) \\
\end{array}$ & $12(39 \%)$ & \multirow[t]{2}{*}{13.4} & \multirow[t]{2}{*}{$0.0002 *$} \\
\hline Normal & 2 & 17 & $19(61 \%)$ & & \\
\hline \multicolumn{6}{|l|}{ Blood pressure (BP) } \\
\hline Shock & 11 & 5 & $16(52 \%)$ & \multirow{2}{*}{15.9} & \multirow{2}{*}{$0.0006^{*}$} \\
\hline Normal & 0 & 15 & $15(48 \%)$ & & \\
\hline \multicolumn{6}{|l|}{ Conscious level } \\
\hline Coma & 6 & 2 & $8(26 \%)$ & \multirow{2}{*}{7.4} & \multirow{2}{*}{$0.006^{*}$} \\
\hline Normal & 5 & 18 & $23(74 \%)$ & & \\
\hline \multicolumn{6}{|l|}{ Vomiting } \\
\hline Yes & 7 & 8 & $15(48 \%)$ & \multirow{2}{*}{1.6} & \multirow{2}{*}{0.2} \\
\hline No & 4 & 12 & $16(52 \%)$ & & \\
\hline
\end{tabular}

n: number, * significant

The laboratory analysis of studied patients revealed, $19 \%$ of the studied patients had abnormal blood sugar, $45 \%$ had metabolic acidosis, $10 \%$ had abnormal liver function test and no patients had renal abnormalities. The statistical analysis revealed significant difference between both groups as regards blood sugar and acid base status and no significant difference as regards liver and renal function tests (Table 3).

Table (3): Statistical analysis of the laboratory analysis for both studied groups.

\begin{tabular}{|c|c|c|c|c|c|}
\hline Parameters & $\begin{array}{c}\text { Non survivor } \\
\text { group } \\
\mathbf{n}=\mathbf{1 1} \\
\end{array}$ & $\begin{array}{c}\text { Survivor } \\
\text { group } \\
\mathbf{n}=\mathbf{2 0} \\
\end{array}$ & $\begin{array}{l}\text { Total } \\
\mathbf{n}=\mathbf{3 1}\end{array}$ & $\begin{array}{c}\text { Chi-square } \\
\text { test }\left(\chi^{2}\right)\end{array}$ & $\mathbf{p}$ \\
\hline \multicolumn{6}{|c|}{ Random blood glucose level } \\
\hline Abnormal & & & & \multirow{4}{*}{13.5} & \multirow{4}{*}{$0.0002^{*}$} \\
\hline a) Hyperglycemia & 5 & 0 & $6(19 \%)$ & & \\
\hline b) Hypoglycemia & 1 & 0 & $6(19 \%)$ & & \\
\hline Normal & 5 & 20 & $25(81 \%)$ & & \\
\hline \multicolumn{6}{|l|}{ Acid - base status } \\
\hline Metabolic acidosis & 10 & 4 & $14(45 \%)$ & \multirow{2}{*}{14.4} & \multirow{2}{*}{$0.0001^{*}$} \\
\hline Normal & 1 & 16 & $17(55 \%)$ & & \\
\hline \multicolumn{6}{|c|}{ Abnormal liver function tests } \\
\hline Yes & 1 & 2 & $3(10 \%)$ & \multirow{2}{*}{0.007} & \multirow{2}{*}{0.9} \\
\hline No & 10 & 18 & $28(90 \%)$ & & \\
\hline \multicolumn{6}{|c|}{ Abnormal renal function tests } \\
\hline Yes & 0 & 0 & $0(0 \%)$ & \multirow{2}{*}{0} & \multirow{2}{*}{1} \\
\hline No & 11 & 20 & $31(100 \%)$ & & \\
\hline
\end{tabular}

$\mathrm{n}$ : number, * significant 
The cardiac arrhythmia was apparent in $39 \%$ of the patients, (seven patients in the non survivor group had ECG abnormalities: two patients had ventricular tachycardia (VT), two patients had bradycardia, one patient had premature ventricular contractions (PVC), one patient had atrial fibrillation (AF) and one patient had ischemic changes, versus five patients in the survivor group: one patient had bradycardia, one patient had PVC, two patients with ischemic changes and one patient had nodal rhythm). The statistical analysis revealed significant difference between both groups as regard ECG abnormalities (Table 4).

Table (4): Statistical analysis of the ECG abnormalities for both studied groups

\begin{tabular}{|l|c|c|c|c|c|}
\hline \multicolumn{1}{|c|}{ Parameters } & $\begin{array}{c}\text { Non survivor } \\
\text { group } \\
\mathbf{n = 1 1}\end{array}$ & $\begin{array}{c}\text { Survivor } \\
\text { group } \\
\mathbf{n = 2 0}\end{array}$ & $\begin{array}{c}\text { Total } \\
\mathbf{n = 3 1}\end{array}$ & $\begin{array}{c}\text { Chi-square } \\
\text { test }\left(\chi^{2}\right)\end{array}$ & $\mathbf{p}$ \\
\hline $\begin{array}{l}\text { Cardiac Arrhythmia } \\
\text { Total number }\end{array}$ & 7 & 5 & & & \\
VT & $(2)$ & $(0)$ & & & \\
Bradycardia & $(2)$ & $(1)$ & $12(39 \%)$ & & \\
PVC & $(1)$ & $(1)$ & & \\
AF & $(1)$ & $(0)$ & & & \\
Ischemic changes & $(1)$ & $(2)$ & & & \\
Nodal rhythm & $(0)$ & $(1)$ & & & \\
\hline Normal & 4 & 15 & $19(61 \%)$ & & \\
\hline
\end{tabular}

$\mathrm{n}$ : number, * significant

The inotropic therapy was given in $52 \%$ of the patients and in $32 \%$ NAC was given and there is significant difference between both groups as regard the usage of inotropes and NAC (Table 5).

Table (5): Statistical analysis of the given therapy for both studied groups.

\begin{tabular}{|c|c|c|c|c|c|}
\hline Parameters & $\begin{array}{l}\text { Non survivor } \\
\text { group } \\
\mathbf{n}=\mathbf{1 1}\end{array}$ & $\begin{array}{c}\text { Survivor } \\
\text { group } \\
\mathbf{n}=\mathbf{2 0}\end{array}$ & $\begin{array}{l}\text { Total } \\
\mathbf{n}=\mathbf{3 1}\end{array}$ & $\begin{array}{c}\text { Chi-square test } \\
\qquad\left(\chi^{2}\right)\end{array}$ & $\mathbf{p}$ \\
\hline \multicolumn{6}{|c|}{ Inotropic therapy } \\
\hline Yes & 11 & 5 & $16(52 \%)$ & \multirow{2}{*}{15.9} & \multirow{2}{*}{$0.00006^{*}$} \\
\hline No & 0 & 15 & $15(48 \%)$ & & \\
\hline \multicolumn{6}{|l|}{ NAC therapy } \\
\hline Yes & 6 & 4 & $10(32 \%)$ & \multirow{2}{*}{3.9} & \multirow{2}{*}{$0.05 *$} \\
\hline No & 5 & 16 & $21(68 \%)$ & & \\
\hline
\end{tabular}

n: number, ${ }^{*}$ significant

The mortality of the moderate to severe patients who received NAC was $60 \%$ versus $83 \%$ in those moderate to severe who did not receive NAC and no significant difference between both groups as regard the mortality (Table 6). 
Table (6): Statistical comparison of mortality in patients who received NAC and patients did not receive NAC in the moderate to severe patients

\begin{tabular}{|l|c|c|c|c|}
\hline & $\begin{array}{c}\text { NAC therapy } \\
\mathbf{n = 1 0}\end{array}$ & $\begin{array}{c}\text { No NAC therapy } \\
\mathbf{n = 6}\end{array}$ & Chi-square test (x) & p \\
\cline { 1 - 4 } Survivor group & $4(40 \%)$ & $1(17 \%)$ & \multirow{2}{*}{0.95} & \multirow{2}{*}{0.3} \\
\cline { 1 - 3 } Non survivor group & $6(60 \%)$ & $5(83 \%)$ & & \\
\cline { 1 - 5 } Total & 10 & 6 & & \\
\hline
\end{tabular}

n: number.

A logistic regression analysis of the significant parameters revealed that the tachycardia, shock, coma, hyperglycemia, metabolic acidosis, cardiac arrhythmia and usage of inotropic therapy are predictors of mortality (Table 7).

Table (7): Logistic regression analysis of the significant parameters to detect predictors associated with aluminium phosphide poisoning-related mortality.

\begin{tabular}{|c|c|c|c|c|}
\hline Parameters & $\begin{array}{l}\text { Non survivor } \\
\text { group } n=11\end{array}$ & $\begin{array}{c}\text { Survivor group } \\
n=20\end{array}$ & OR $(95 \% C I)$ & $\mathbf{p}$ \\
\hline \multicolumn{5}{|l|}{ Heart rate (HR) } \\
\hline Abnormal & 9 & 3 & \multirow{2}{*}{$\begin{array}{c}26 \\
4 \text { to } 182\end{array}$} & \multirow{2}{*}{$0.001^{*}$} \\
\hline Normal & 2 & 17 & & \\
\hline \multicolumn{5}{|c|}{ Blood pressure (BP) } \\
\hline Shock & 11 & 5 & \multirow{2}{*}{$\begin{array}{c}65 \\
3 \text { to } 1294\end{array}$} & \multirow{2}{*}{$0.006^{*}$} \\
\hline Normal & 0 & 15 & & \\
\hline \multicolumn{5}{|l|}{ Conscious level } \\
\hline Coma & 6 & 2 & \multirow{2}{*}{$\begin{array}{c}11 \\
2 \text { to } 71 \\
\end{array}$} & \multirow{2}{*}{$0.01 *$} \\
\hline Normal & 5 & 18 & & \\
\hline \multicolumn{5}{|c|}{ Random blood glucose level (mg/dl) } \\
\hline Abnormal & 6 & 0 & \multirow{2}{*}{$\begin{array}{c}49 \\
2 \text { to } 999 \\
\end{array}$} & \multirow{2}{*}{$0.01 *$} \\
\hline Normal & 5 & 20 & & \\
\hline \multicolumn{5}{|c|}{ Acid - base status } \\
\hline $\begin{array}{l}\text { Metabolic } \\
\text { acidosis }\end{array}$ & 10 & 4 & \multirow{2}{*}{$\begin{array}{c}40 \\
4 \text { to } 411\end{array}$} & \multirow[t]{2}{*}{$0.002 *$} \\
\hline Normal & 1 & 16 & & \\
\hline \multicolumn{5}{|l|}{ ECG results } \\
\hline $\begin{array}{l}\text { Cardiac } \\
\text { arrhythmia }\end{array}$ & 7 & 5 & \multirow{2}{*}{$\begin{array}{c}5 \\
1 \text { to } 26\end{array}$} & \multirow[t]{2}{*}{$0.04^{*}$} \\
\hline Normal & 4 & 15 & & \\
\hline \multicolumn{5}{|c|}{ Inotropic therapy } \\
\hline Yes & 11 & 5 & \multirow{2}{*}{$\begin{array}{c}65 \\
3 \text { to } 1294 \\
\end{array}$} & \multirow{2}{*}{$0.006^{*}$} \\
\hline No & 0 & 15 & & \\
\hline
\end{tabular}

n: number, ${ }^{*}$ significant, $\mathrm{OR}=$ odds ratio, $\mathrm{CI}=$ confidence interval. 


\section{Discussion}

Aluminum phosphide is a highly toxic pesticide that is used widely in agriculture since 1940s. Aluminum phosphide poisoning is common either accidental or suicidal reasons and is a serious public health problem in developing countries. Because of high toxicity and no existence of effective antidote, ALP poisoning has a high mortality rate (Vahdati et al., 2015).

The grading of the patients was done according to poisoning severity score (Persson et al., 1998), and revealed that 11 patients were asymptomatic, 4 patients had minor toxicity (presented with vomiting only) and 16 patients had moderate to severe toxicity (presented with end organ damage). The study revealed that the mortality rate was $35 \%$ (11 patients out of 31 patients). Similar results were obtained by Sulaj et al. (2015) who studied 317 ALP cases with 140 fatalities and death ratio of $44 \%$. Also, Nosrati et al. (2013) found in Iran between 2000 and 2007 that ALP poisoning caused 146 deaths with mortality rate $24 \%$. Higher incidence of mortality was noted by Aziz and Husain, (2015) where they studied 100 patients with ALP poisoning and total 78 patients died, depicting a $78 \%$ mortality rate. In contrast lesser mortality rate was detected by Lauterbach et al. (2005) where they reported in Germany, between 1983 and 2003, two deaths only out of 188 cases of ALP poisoning and in UK only one resulted in a death out of 93 cases of ALP poisoning.

The study revealed that male patients represent $65 \%$ of the cases and the mean age of the patients was $23 \pm 14$ years in survivor group versus $25 \pm 11$ years in the non survivor and no significant difference between both groups as regard gender and age. The predominance of males may be due to that aluminium phosphide is not a household product and it is commonly available in agricultural field and crop stores where male are more exposed.

Similar results were obtained by Aziz and Husain (2015) who studied 100 patients with ALP poisoning at Allied Hospital Faisalabad and found that $63 \%$ of the cases were males with mean age was $26.7 \pm 7.9$ years. Also, Khodabandeh et al. (2014) in their study found that male-female ratio in favor of men $(55: 45)$ and with mean age of patients was $26 \pm 8$ years. In contrast, Taghaddosinejad and Esmaeil. (2016) studied 63 Patients with ALP poisoning; they found that most of the patients were females $(56.5 \%)$. Also, Sulaj et al. (2015) studied 317 AIP intoxications, the victims mainly belong to the third or fourth decade of life.

The study revealed that $84 \%$ of the cases were suicidal and $16 \%$ were accidental and no significant difference between both groups as regard mode of poisoning. Similar result was obtained by Sulaj et al. (2015) who did a study in five-year period registered a total of 317 AIP intoxication and (94\%) were suicidal. Also, Nosrati et al. (2013) found in Iran more than 90 $\%$ of ALP poisonings were suicidal. While in contrast, Lauterbach et al. (2005) reported in Germany 188 cases of ALP poisoning between 1983 and 2003, $65 \%$ of which was accidental and the remaining was intentional poisoning.

As regard clinical manifestation the results revealed that $39 \%$ of the patients had abnormal heart rate, $52 \%$ were shocked, $26 \%$ had coma and $48 \%$ had vomiting. The statistical analysis revealed significant difference between both groups as regard heart rate, blood pressure and level of consciousness. Similar results was obtained by Aziz and Husain, (2015) who studied 80 patients with acute ALP poisoning and found tachycardia in $85 \%$ of the patients, bradycardia in $15 \%$ and hypotension was observed in 94\%. Moreover, Sulaj et al. (2015) found that among 140 patients, whom died out of 317 in his study of ALP, 92\% had 
cardiovascular collapse, $37 \%$ had coma and $46 \%$ had vomiting. Also, Erfantalab et al. (2017) demonstrated that blood pressure and pulse rate were significantly different between ALP survivors and non-survivors groups.

As regard laboratory analysis the results revealed that $19 \%$ had abnormal blood sugar, $45 \%$ had metabolic acidosis, $10 \%$ had abnormal liver function tests and no one had renal abnormalities. The statistical analysis revealed significant difference between both groups as regard blood sugar and acid base status. Similar results were obtained by Sulaj et al. (2015) who found that among 140 patients whom died out of 317 in his study of ALP poisoning, $88 \%$ had metabolic acidosis and $16 \%$ had hyperglycemia. Also, Erfantalab et al. (2017) demonstrated that the blood $\mathrm{pH}$, and serum bicarbonate level were significantly different between survivors and non-survivors groups.

The results revealed that $39 \%$ had ECG abnormalities; the statistical analysis revealed that there was significant difference between non survivor and survivor groups as regarded ECG abnormalities. Also, Aziz and Husain, (2015) studied 80 patients with acute ALP poisoning and found that $10 \%$ developed cardiac arrhythmia and the most frequent arrhythmia was atrial fibrillation $(31 \%$ of patients) followed by ventricular fibrillation (20\%), ventricular tachycardia (17\%) and AV block (12\%). Moreover, Sulaj et al. (2015) in their study of 317 ALP poisoned patients found that $44 \%$ had sinus tachycardia and $11 \%$ had other cardiac rhythm disorders.

The results revealed that $52 \%$ of the patients need inotropic therapy and in 32\% NAC was received and there were significant difference between both groups as regard inotropic and NAC used. As regard NAC there was limitation in our study where we had 16 patients graded moderate to severe and must take NAC according to our local guidelines but due to unavailability of the drug only 10 patients received NAC so we cannot use their results in the prediction of outcome. At the same time we got benefit from this limitation in comparing between patients who received NAC and patients who did not received NAC in the 16 moderate to severe cases. As showing the mortality rate in the patients who received NAC was $60 \%$ (6 died out of 10 patients) while mortality in the group did not receive NAC was $83 \%$ ( 5 died out of 6 patients) and the statistical analysis revealed no significant difference between both groups.

Similar results obtained by Karanth and Nayyar (2003) where they found that treatment with NAC in ALP poisoning had no therapeutic advantage. In contrast, Bhat et al. (2015) found that among 26 patients treated with NAC out of 100 ALP poisoning patients, mortality in the treated patients was $2 \%$ versus $21.6 \%$ in non treated patients and the difference was statistically significant. Moreover, Tehrani et al. (2013) found that NAC prolong survival time, stabilize blood pressure and pulse rate. Also, Agarwal et al. (2014) found that NAC lower mortality, hospitalization time, and the frequency of intubation and mechanical ventilation.

The logistic regression analysis revealed that tachycardia, shock, coma, hyperglycemia, metabolic acidosis, cardiac arrhythmia and the need of inotropic therapy were predictors of mortality in acute ALP. Similar results were obtained by Mathai and Bhanu (2010) where they found that hypotension requiring vasoactive drugs, low $\mathrm{pH}$, coma and need for mechanical ventilation were predictive of mortality from acute ALP poisoning. While Sulaj et al. (2015) found that the negative prognostic factors related to the fatalities were high dosage of the toxic agent, the long delay (a mean of 4 hours); the lack of vomiting, and the depth of coma upon presentation. 


\section{Conclusion}

Aluminum phosphide is a low-cost highly-toxic rodenticide. The circulatory collapse, metabolic acidosis and cardiac arrhythmia are the major causes of death. The role of NAC must be reassessed in larger scale. So, intensive observation in ICU and aggressive symptomatic management should be urgently taken into consideration.

\section{Recommendations}

- People handling this fumigant must be aware of its lethal aspects.

- They should be prohibited from keeping and using this poison at the home.

- They should be advised to cover the tablets in open fields after use.

- They should keep their tablets away from the reach of children and other family members.

- Official health care system should restrict the open sales of this pesticide.

- Vendors and shop keepers should not sell the tablets to young people and children without proper verification and confirmation.

- If possible all of the phosphide derivatives compounds should be forbidden forever for everyone.

\section{Acknowledgment}

We would like to thank the Director as well as the medical and nursing staff of the Poison Control Center, Ain Shams University Hospitals for their help and support.
References

Agarwal, A.; Robo, R. and Jain, N. (2014): "Oxidative stress determined through the levels of antioxidant enzymes and the effect of $\mathrm{N}$-acetylcysteine in aluminum phosphide poisoning". Indian J. Crit. Care Med., 18:666- 671.

Anand, R.; Sharma, D. and Verma, D.( 2013): "Mitochondrial electron transport chain complexes, catalase and markers of oxidative stress in platelets of patients with severe aluminum phosphide poisoning". Hum. Exp. Toxicol., 32:807-816.

Aziz, U. and Husain, A. (2015): "Frequency of cardiac arrhythmias in patients with aluminum phosphide poisoning". Asia Pacific Journal of Medical Toxicology, 4: 4.

Bhat, S.; Kumar, P. and Kenchetty, A. (2015): "mortality N-Acetyl cysteine in the management of rodenticide consumption - life saving"? Journal of Clinical and Diagnostic Research, 9:10-13.

Erfantalab, A.; Kambiz, S. and Shahin S. (2017): "Trend of blood lactate level in acute aluminum phosphide poisoning". World J. Emerg. Med., 8: 2116-2120.

Gurjar, M.; Baronia, A. and Azim, A. (2011): "Managing aluminum phosphide poisonings". J. Emerg. Trauma Shock, $4: 378-384$.

Hassanian, M. (2014): "Phosphides and phosphine: Mechanisms for toxicity and range of the problem". Clin. Toxicol., 52:397-398.

Karanth, S. and Nayyar, V. (2003):" Rodenticide - induced hepatotoxicity". J. Assoc. Physicians India, 51:816-817. 
Khodabandeh, F.; Kahani, A. and Soleimani, G. (2014): "The study of fatal complications of "rice tablet" poisoning". SJFM., 20: 27-36.

Lauterbach, M.; Solak, E. and Kaes, J. (2005): "Epidemiology of hydrogen phosphide exposures in humans reported to the poison center in Mainz, Germany, 1983-2003". Clin. Toxicol. Phila., 43:575-581.

Mathai, A. and Bhanu, M. (2010): "Acute aluminium phosphide poisoning: Can we predict mortality? "Indian Journal of Anaesthesia, 54(4): 302-307.

Nosrati, A.; Karami, M. and Esmaeilnia, M. (2013): "Aluminum phosphide poisoning: A case series in north Iran". Asia Pac. J. Med. Toxicol., 2:111-113.

Persson, H.; Sjöberg, G.; Haines, J. and Pronczuk de Garbino, J. (1998): "Poisoning severity score: Grading of acute poisoning". J. Toxicology Clinical Toxicology, 36:205-213.
Sulaj, Z.; Drishti, A. and Çeko, I. (2015):

"Fatal aluminum phosphide poisonings in Tirana (Albania), 2009 - 2013". DARU Journal of Pharmaceutical Sciences, 23:28.

Taghaddosinejad, A. and Esmaeil, F. (2016): "The effect of N-acetyl cysteine (NAC) on aluminum phosphide poisoning inducing cardiovascular toxicity: a casecontrol study". Available at http// 5:1948 DOI 10.1186/s40064-016-3630-2 RESEARCH.

Tehrani, H.; Halvaie, Z. and Shadnia, S. (2013): "Protective effects of Nacetylcysteine on aluminum phosphideinduced oxidative stress in acute human poisoning". Clin. Toxicol. Phila., 51:2328.

Vahdati, S.; Moghadam, R.; Vandrajabpour, Z. and Paknejad, P. (2015): "Successful outcome in managing of aluminum phosphide poisoning". Journal of Emergency Practice and Trauma, 1: 67-68. 


\section{دراسة أسباب الوفاة فى حالات التسمم الحاد بفوسفيد الالمونيوم}

\section{هانى محمد توفيق}

مركز علاج التسمم مستثفيات جامعة عين شمس مدس

أثنار تسمم فوسفيد الألومنيوم الاهتمام بزيادة عدد الحالات في العقود الثنلاثة الماضية. على الرغم من أن

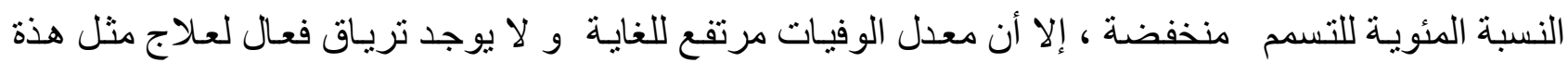

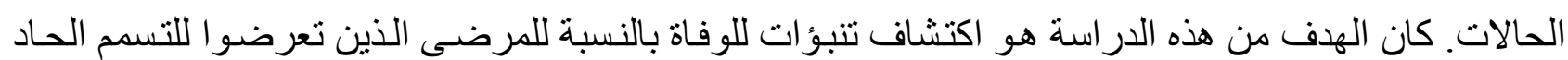

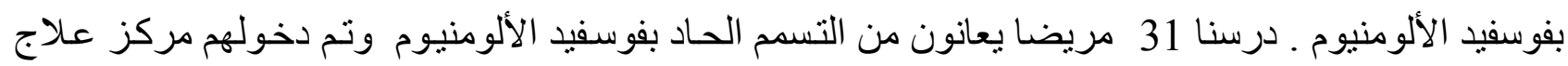

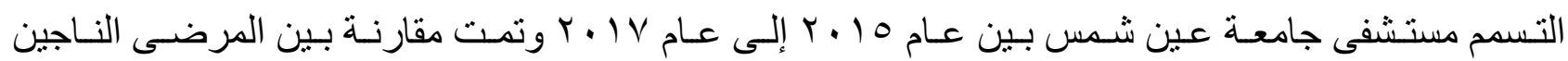

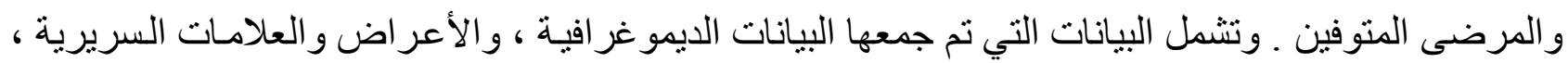

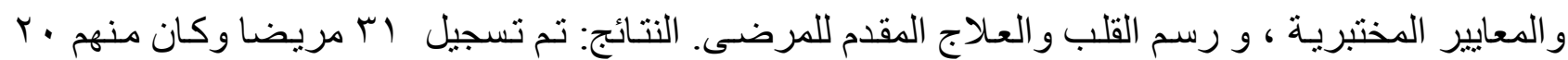

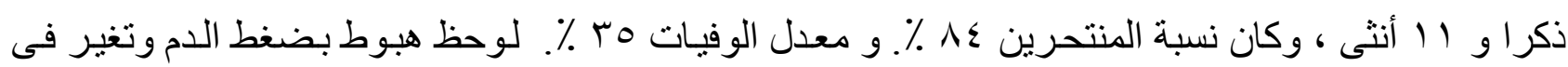

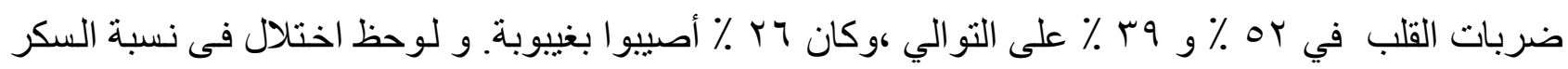

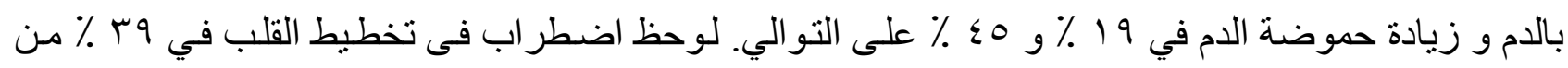

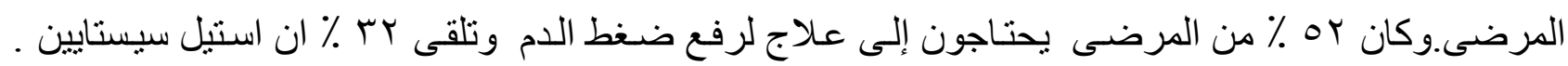

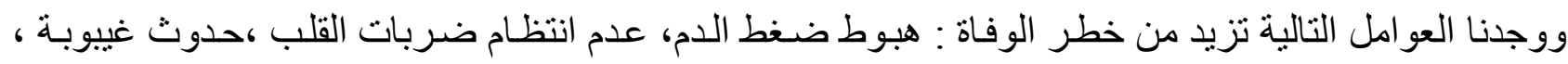

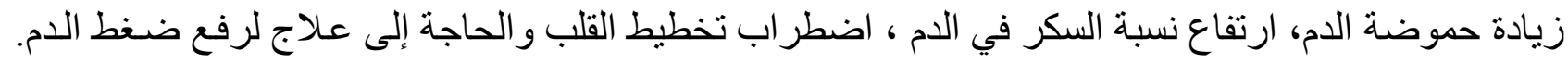
و نخلص إلى أن فوسفيد الألومنيوم هو مبيد عالي السمية منخفضة التكلفة، ويعنبر هبوط الدورة الدمويـة، زيادة حموضة الدم و عدم انتظام ضربات القلب هي الأسباب الرئيسية للوفاة. لم يكن هنـاك تريساق فعـال متاح للعـلاج

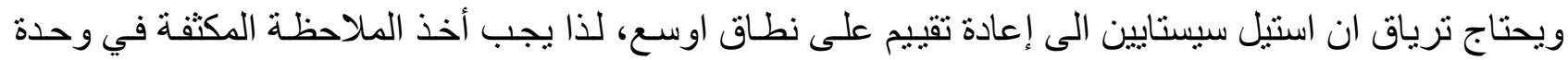

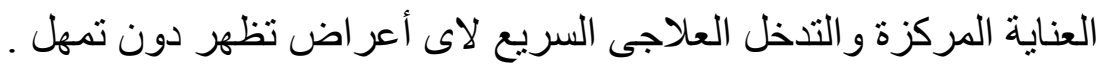

